\title{
Menciptakan Kepuasan Konsumen Dengan Pengalaman Membeli Produk
}

\author{
Sukma Irdiana ${ }^{1}$, Mohammad Noor Khairullah ${ }^{2}$ \\ Program Studi Manajemen, STIE Widya Gama Lumajang \\ Email: sukmapasah@gmail.com
}

https://doi.org/ 10.30741/adv.v3i2.484

\section{N F O A R T I K E L}

Tanggal masuk :

25 Oktober 2019

Tanggal Revisi :

28 November 2019

Tanggal Diterima :

31 Desember 2019

\section{A B S T R A K}

Jumlah pemakai internet saat ini di Indonesia makin hari kian bertambah, seiring dengan berkembangnya kemajuan jaman dan teknologi. Salah satunya adalah penyediaan layanan pesan antar makanan. Pada riset kali ini, peneliti memiliki tujuan untuk mendeskripsikan seberapa jauh pengaruh pengalaman membeli konsumen terhadap kepuasan serta keinginan untuk membeli kembali secara online pada GoFood di Surabaya. Data riset ini diperoleh melalui penyebaran kuesioner pada 70 responden dengan metode accidental Sampling bagi pemesan GoFood di Kota Surabaya yang sering membeli menggunakan GoFood secara online peling sedikit 3 kali dalam jangka waktu 2 bulan. Teknik pengujian data yang dilakukan dalam riset ini adalah Partial Least Square. Hasil riset membuktikan bahwa pengalaman membeli dan kepuasan konsumen secara online terkadang tidak memberikan rangsangan untuk melakukan pembelian ulang pada konsumen. Namun kepuasan pelanggan yang optimal dapat mengakibatkan pembelian ulang pada suatu produk atau jasa yang diberikan. Hal ini karena pengalaman membeli dan kepuasan konsumen tidak menjamin konsumen untuk membeli kembali suatu produk. Akan tetapi jika konsumen merasa puas maka konsumen secara spontan akan melakukan pembelian ulang. Bahkan jika konsumen puas maka konsumen akan secara tidak langsung mempromosikan produk ke konsumen yang lainnya.

Kata Kunci: Pengalaman Membeli, Kepuasan Konsumen, Niat Membeli Ulang

\begin{abstract}
A B S T R A C T
The number of internet users currently in Indonesia is increasingly growing, along with the development of the times and technology. One of them is the provision of food delivery services. In this research, researchers have the aim to describe how far the influence of the consumer buying experience on satisfaction and the desire to buy back online at GoFood in Surabaya. This research data was obtained through distributing questionnaires to 70 respondents using the accidental sampling method for ordering GoFood in Surabaya, who often bought using GoFood online at least three times in a period of 2 months. The data testing technique used in this research is Partial Least Square. The research proves that buying experience and online customer satisfaction sometimes does not provide a stimulus to repurchase consumers. However, optimal customer satisfaction can result in repurchases on a product or service provided. This is because buying experience and customer satisfaction does not guarantee consumers to buy back a product. However, if consumers are satisfied, consumers will
\end{abstract}


spontaneously make repeat purchases. Even if consumers are satisfied, consumers will indirectly promote products to other consumers.

Keywords: Experience Buying, Customer Satisfaction, Repurchase Intention

\section{PENDAHULUAN}

Penyedia layanan pesan antar makanan yang dimiliki GoFood, tercatat mencapai 2,43 kali pertumbuhan mitra UMKM atau sebanyak 96 persen dari tahun 2018 (Tempo.Co, 2019). Pentingnya kualitas layanan elektronik dan kualitas makanan pada kepuasan dalam layanan pengiriman makanan online, memiliki hubungan yang tidak langsung terhadap kepuasan pelanggan sehingga pelanggan akan cenderung berbelanja ulang dan menganjurkan kepada orang lain untuk membeli barang tersebut (Suhartanto, Dean, \& Leo, 2019). Pengalaman ini yang membuat pelanggan akan terus membeli makanan tersebut walaupun harga dari makanan tersebut naik. Salah satu factor berkembangnya pesan-antar makanan ini adalah program promosi yang kerap ditawarkan kepada para konsumen. Pengalaman adalah suatu peristiwa yang dirasakan oleh individu yang dapat memberikan kesan yang berarti bagi pelanggan (Schmitt, 1999).

Pengalaman membeli merupakan hubungan antara pembeli dengan barang. Perusahaan yang memproduksi dapat mengorientasikan pada keingian konsumen. Pengalaman membeli lebih bersifat pribadi yang menyiratkan pada keterlibatan pelanggan dengan perasaaan. Pengalaman membeli secara online dapat mempengaruhi niat membeli ulang konsumen secara online (Huang, Wu, Wang, \& Boulanger (2011); (Monsuwé, Dellaert, \& De Ruyter, 2004); Weisberg, Te'eni, \& Arman (2011)). Dalam pengalaman membeli terdapat enam komponen didalamnya diantaranya : 1) Sensorik. Panca indra yang ada pada tubuh manusia yang dapat menimbulkan rangsangan untuk melakukan suatu tindakan. 2) Emosional. Perasaan seseorang yang timbul untuk memdapatkan suatu keinginan. 3) Kognitif. Potensi intelektual manusia dalam hal memilih keinginan. 4) Pragmatis. Aliran filsafat yang mengajarkan suatu tindakan untuk memilih sesuatu yang benar. 5) Gaya Hidup. Kebutuhan sekunder manusia dalam memenuhi suatu keinginan. 6) Relasional. Tindakan yang diakibatkan atas suatu hal yang ada. (Schiffman \& Kanuk, 2004).

Kepuasan konsumen berakumulasi dengan sikap dan pengalaman membeli (Fornell, 2016). Kepuasan konsumen adalah kebahagiaan seseorang atas suatu barang yang dibeli sesuai dengan apa yang diharapkan. Konsumen dapat dikatakan puas apabila konsumen terlebih dahulu memiliki pengalaman membeli baik itu secara offline maupun online, karena kepuasan akan muncul apabila konsumen sudah pernah membeli dan merasa puas atau cocok dengan apa yang diinginkannya. Terlebih pada konsumen online yang hanya dapat berbelanja dengan melihat fiture dari situs atau toko online. Konsumen online akan puas apabila barang yang dibeli sama dengan fiture atau gambar yang di tampilkan oleh toko online, namun konsumen akan merasa tidak puas apabila konsumen online tidak mendapatkan kesamaan barang dengan apa yang ditampilkan di fiture atau toko online (Kim \& Stoel, 2004). Kepuasan konsumen yang optimal dapat mengakibatkan konsumen membeli ulang secara online (Ha, Janda, \& Muthaly (2010); Lin \& Lekhawipat (2014); Trisnawati, Suroso, \& Kumorohadi (2012).

Kepuasan konsumen yang sempurna akan berdampak pada pembelian secara berulang-ulang. Minat beli ulang menurut Nurhayati \& Murti (2012) adalah suatu tindakan yang dilakukan oleh konsumen dalam membeli kembali suatu barang, yang dapat mengakibatkan rasa puas yang didapat dari membeli suatu produk yang dinginkan. Merk yang sudah melekat di benak konsumen dapat mengakibatkan konsumen melanjutkan kembali pembelian atau pembelian ulang. Mengingat perkembangan yang terjadi saat ini, baik perkembangan pada diri konsumen bila dilihat dari kesuakaan, kepribadian, social dan budaya. Hal ini akan berdampak pada proses pengambilan keputusan untuk membeli ulang suatu produk. Penelitian niat membeli ulang pernah dilakukan 
oleh Saidani \& Arifin (2012), Hendarsono \& Sugiharto (2013), Resti \& Soesanto (2016) mengatakan bahwa kepuasan konsumen yang optimal dapat menyebabkan konsumen membeli kembeli produk yang pernah dibeli atau ditawarkan. Tujuan dalam riset ini adalah untuk membuktikan seberapa jauh pengaruh pengalaman membeli konsumen terhadap kepuasan dan niat membeli ulang secara online pada GoFood di Surabaya.

\section{METODE PENELITIAN}

Jenis penelitian yang dipakai adalah explanatory (penjelasan) dengan pendekatan kuantitatif. Lokasi riset dilakukan pada konsumen GoFood di Surabaya. Populasi pada penelitian ini adalah populasi tak terhingga (infinite population). Menurut Malhotra (2009), sampel paling sedikit empat sampai lima kali dari jumlah item pertanyaan. Sampel pada riset ini sebanyak 70 orang responden (14 item pertanyaan X5), dengan teknik sampling menggunakan accidental Sampling. Data yang diperoleh dari riset ini berasal dari data primer. Teknik pengujian data yang dipakai adalah path analysis.

\section{HASIL DAN PEMBAHASAN}

Pada penelitian ini proses penyebaran kuesioner ditujukan kepada 70 responden yaitu konsumen GoFood. Dengan kriteria konsumen telah membeli produk di Bukalapak selama 1 bulan lebih dari 2 kali. Responden pada riset ini terdiri atas 42 perempuan dan 28 laki-laki. Usia 21 - 30 tahun sejumlah 22 reponden, 31 - 40 tahun sejumlah 34 responden, $41-50$ tahun sejumlah 8 , dan $>50$ tahun sejumlah 6 responden. Pendidikan SMA/SMU sebanyak 21 responden, S1 sebanyak 39 responden, S2 sebanyak 7 responden, dan S3 sebanyak 3 reponden. Dalam riset ini uji validitas dan uji reliabilitas dinyatakan telah memenuhi syarat yang telah ditentukan. Berikut adalah hasil uji analisis jalur antara variabel Pengalaman Membeli, Kepuasan Konsumen, dan Niat Membeli Ulang.

Tabel 1. Hasil Uji Analisis Jalur

\begin{tabular}{|c|c|c|c|c|c|c|}
\hline Hipotesis & $\begin{array}{l}\text { Variabel } \\
\text { Endogen }\end{array}$ & $\begin{array}{l}\text { Variabel } \\
\text { Eksogen }\end{array}$ & Beta & $\mathbf{t}_{\text {hitung }}$ & Probabilitas & Keterangan \\
\hline H1 & $\begin{array}{l}\text { Pengalaman } \\
\text { Membeli }\end{array}$ & $\begin{array}{l}\text { Kepuasan } \\
\text { Konsumen }\end{array}$ & 0,195 & 1,142 & 0,262 & $\begin{array}{l}\text { Tidak } \\
\text { Signifikan }\end{array}$ \\
\hline $\mathrm{H} 2$ & $\begin{array}{l}\text { Pengalaman } \\
\text { Membeli }\end{array}$ & $\begin{array}{l}\text { Niat } \\
\text { Membeli } \\
\text { Ulang }\end{array}$ & 0,070 & 0,491 & 0,627 & $\begin{array}{l}\text { Tidak } \\
\text { Signifikan }\end{array}$ \\
\hline H3 & $\begin{array}{l}\text { Kepuasan } \\
\text { Konsumen }\end{array}$ & $\begin{array}{l}\text { Niat } \\
\text { Membeli } \\
\text { Ulang }\end{array}$ & 0,597 & 4,193 & 0,000 & Signifikan \\
\hline
\end{tabular}

Sumber : Penulis 2019

H1: Pengalaman Membeli berpengaruh tidak signifikan terhadap Kepuasan Konsumen. Berdasarkan tabel 1, hasil uji analisis jalur menunjukkan adanya hubungan antara variabel Pengalaman Membeli dengan Kepuasan Konsumen, menunjukkan angka Koefisien beta sebesar 0,195. Hasi uji $t_{\text {hitung }}$ diperoleh sebesar 1,142 dengan probabilitas sebesar 0,262 (p>0,05) maka keputusannya adalah HO di terima. Dalam arti adanya hubungan langsung namun tidak signifikan dari variable pengalaman membeli ke kepuasan konsumen.

H2: Pengalaman Membeli berpengaruh tidak signifikan terhadap Niat Membeli Ulang. Berdasarkan tabel 1, hasil uji analisis jalur menunjukkan adanya hubungan antara variabel Pengalaman Membeli dengan Niat Membeli Ulang, menunjukkan angka Koefisien beta sebesar 0,070. Hasi uji $t_{\text {hitung }}$ diperoleh sebesar 0,491 dengan probabilitas sebesar 0,627 (p>0,05) maka keputusannya adalah H0 di terima. Dalam arti adanya hubungan langsung namun tidak signifikan dari variable pengalaman membeli ke niat membeli ulang. 
H3: Kepuasan Konsumen berpengaruh signifikan terhadap Niat Membeli Ulang. Berdasarkan tabel 1, hasil uji analisis jalur menunjukkan adanya hubungan antara variabel Kepuasan Konsumen dengan Niat Membeli Ulang, menunjukkan angka Koefisien beta sebesar 0,597. Hasi uji $t_{\text {hitung }}$ diperoleh sebesar 4,193 dengan probabilitas sebesar 0,000 ( $\mathrm{p}<0,05)$ maka keputusannya adalah $\mathrm{H} 0$ di tolak. Dalam arti adanya hubungan langsung yang signifikan dari variable kepuasan konsumen terhadap niat membeli ulang.

Koefisien Determinan (R Square). Besarnya sumbangan (kontribusi) Pengalaman Membeli terhadap Kepuasan Konsumen dapat dilihat dari nilai R Square yaitu sebesar 19,5\%. Artinya bahwa 19,5\% variabel Pengalaman Membeli akan dipengaruhi oleh variabel Kepuasan Konsumen. Sedangkan sisanya 80,5\% variabel Kepuasan Konsumen akan dipengaruhi oleh variabel lain. Besarnya sumbangan (kontribusi) Pengalaman Membeli terhadap Niat Membeli Ulang dapat dilihat dari nilai R Square yaitu sebesar 61,4\%. Artinya bahwa 61,4\% variabel Pengalaman Membeli akan dipengaruhi oleh variabel Niat Membeli Ulang. Sedangkan sisanya 38,6\% variabel Niat Membeli Ulang akan dipengaruhi oleh variabel lain. Besarnya sumbangan (kontribusi) Kepuasan Konsumen terhadap Niat Membeli Ulang dapat dilihat dari nilai R Square yaitu sebesar $61 \%$. Artinya bahwa $61 \%$ variabel Kepuasan Konsumen akan dipengaruhi oleh variabel Niat Membeli Ulang. Sedangkan sisanya 39\% variabel Niat Membeli Ulang akan dipengaruhi oleh variabel lain.

Hasil riset ini membuktikan bahwa adanya pengaruh namun tidak signifikan antara pengalaman membeli dengan kepuasan konsumen. Dimana pengalaman membeli yang dirasakan konsumen pada saat berkunjung ke website GoFood. Awalnya konsumen bersemangat untuk memilih dan membeli, namun setelah barang yang dipesan itu datang. Konsumen terkadang merasa kecewa. Kekecewaan ini disebabkan karena apa yang ditampilkan oleh website terkadang tidak sama dengan kenyataan terutama model (bentuk) serta rasanya. Sehingga membuat konsumen enggan untuk memesan kembali makanan tersebut dan berganti ke makanan lain. Selain itu, terkadang konsumen langsung memilih makanan tanpa memesan atau melihat aplikasi yang disajikan. Semua itu disebabkan karena pengalaman membeli konsumen akan suatu makanan yang pernah konsumen pesan. Hasil riset ini tidak sesuai dengan Suandana, Rahyuda, \& Yasa (2016), Pramudita \& Japarianto (2013), Salim, Catherine, \& Andreani (2015) yang mengatakan bahwa pengalaman membeli dapat mempengaruhi kepuasan dalam membeli suatu produk. Kepuasan konsumen dapat ditinjau dari 1) Perasaan senang (dalam arti senang akan barang dan layanan) Yaitu ungkapan perasaan senang atau tidak senang pelanggan saat menerima layanan yang prima dan produk yang berkualitas dari perusahaan. 2) Selalu membeli produk Yaitu konsumen akan selalu menggunakan produk yang diinginkan. 3) Akan menyarankan kepada orang lain Yaitu pelanggan yang bahagia setelah memakai suatu produk atau jasa pasti akan menceritakan kepada orang lain serta mampu membentuk pelanggan baru bagi suatu perusahaan. 4) Tercapainya keinginan pelanggan setelah membeli produk Yaitu setaranya kualitas produk atau jasa yang dibeli oleh konsumen.

Hasil riset ini mengatakan bahwa adanya pengaruh langsung yang tidak signifikan pada variable pengalaman membeli ke niat membeli ulang. Dalam hal ini yang dirasakan konsumen pada saat memperoleh atau menikmati makanan yang konsumen beli atau pesan. Pengalaman membeli dan menikmati makanan yang dibeli membuat konsumen tertarik untuk memesan kembali makanan yang dibelinya. Dengan semakin seringnya konsumen mendapati makanan yang sesuai dengan cita rasa kegemaran konsumen maka konsumen akan terus membeli secara berulang-ulang. Namun pada riset ini konsumen merasa kurang menikmati makanan yang dipesan. Hal ini salah satunya disebabkan karena cita rasa makanan dan yang kedua adalah adanya makanan yang sudah tidak ada di menu makanan dengan alasan habis atau tidak musim. Sehingga membuat konsumen harus berganti menu dengan terpaksa. Kekecewaan ini yang membuat pelanggan malas untuk memesan kembali makanan tersebut dan membeli makanan di warung terdekat dengan tempat konsumen berada. Hal ini tidak sejalan dengan riset Yolandari \& Kusumadewi (2018), Suandana et al. (2016), Weisberg et al. (2011), Mohmed, Azizan, \& Jali (2013), Adytia \& Yuniawati (2016), 
Kusumawati \& Sutopo (2013), yang mengatakan bahwa pengalaman membeli memberikan dampak positif pada pembelian ulang konsumen. Niat membeli ulang konsumen disebabkan oleh 1) Minat transaksional - kecenderungan konsumen untuk selalu membeli kembali produk yang mereka konsumsi. 2) Minat referensial - kemauan konsumen untuk menyarankan produk kepada orang lain. 3) Minat preferensial - tindakan konsumen untuk mewujudkan produk yang dipilih sebagai pilihan utama. 4) Minat eksploratif - kemauan konsumen untuk mencari masukan produk yang minati.

Hasil riset mengatakan bahwa terdapat keterkaitan secara langsung antara kepuasan konsumen dengan keinginan untuk membeli kembali. Hal ini menjelaskan bahwa apabila konsumen puas dalam membeli makan maka konsumen akan terus memesan kembali makanan tersebut. Selain itu konsumen akan memberikan rekomendasi makanan tersebut ke teman, saudara dan keluarga, atau bahkan masyarakat disekitarnya. Ini akan memberikan masukan yang baik pada warung atau restoran yang menggunakan aplikasi online. Hasil penelitian ini sejalan dengan penelitian sebelumnya yang dilakukan oleh Adixio \& Saleh (2013), Kusuma \& Suryani (2017), Chen \& Chou (2012), Mohmed et al. (2013), dan Baskara \& Sukaatmadja (2016) yang menemukan bahwa kepuasan konsumen merupakan salah satu cara konsumen untuk melakukan pembelian ulang.

\section{KESIMPULAN}

Berdasarkan pembahasan yang telah dilakukan serta kajian hipotesis yang dikembangkan dalam penelitian ini, maka dapat di jelaskan mengenai kesimpulan dari pelaksanaan penelitian ini sebagai berikut : (1) Fasilitas umroh tidak mempunyai pengaruh yang signifikan terhadap persepsi jamaah dalam memilih jasa umroh (2) Biaya perjalanan umroh memiliki pengaruh yang signifikan terhadap persepsi jamaah dalam memilih jasa umroh. (3) Secara simultan fasilitas dan biaya mampu memberikan pengaruh terhadap persepsi yang dimiliki jamaah dalam memilih umroh Pada PT. UDA CS HOLIDAYS INDONESIA.

\section{DAFTAR PUSTAKA}

Chulaifi, M, I., Endang, S. (2018). Pengaruh Kualitas Pelayanan, Persepsi Harga Dan Kepercayaan Terhadap Kepuasan Konsumen Jasa Travel Umrah Dan Haji Pada PT. Sebariz Warna Berkah Di Surabaya. Jurnal Hasil Penelitian LPPM Untag Surabaya. 03, 01. Diakses dari http://jurnal.untag-sby.ac.id/index.php/jhp17/issue/view/144

Fadillah, L. (2019). Strategi Dan Manajemen Travel Haji Dan Umroh (Studi Analisis Persaingan Travel Haji Dan Umroh Kota Medan Dalam Pelayanan dan Kualitas Untuk Meningkatkan jumlah Konsumen. Al-Muamalat : Jurnal Hukum Ekonomi Syariah. 4, 01. 1-24. Diakses dari https://journal.iainlangsa.ac.id/index.php/muamalat/article/view/775

Ghozali, I. (2011). Aplikasi Analisis Multivariate dengan program SPSS. Semarang: Universitas Diponegoro.

Hurriyati, R. (2012). Bauran Pemasaran dan Loyalitas Konsumen. Bandung: Alfabeta.

Kemenag. (2019). Pencarian PPIU (Penyelenggara Perjalanan Ibadah Umrah). tulisan pada https://simpu.kemenag.go.id/home/travel.

Kotler, P. (2013). Dasar-dasar Pemasaran. Jakarta: Intermedia.

Lempoy, N, C., Silvya, L, M., Sjendry, S, R, L. (2015). Pengaruh Harga, Lokasi, Dan Fasilitas Terhadap Keputusan Menggunakan Jasa Taman Wisata Toar Lumimuut (Taman Eman) Sonder. Jurnal EMBA: Jurnal Riset Ekonomi, Manajemen, Bisnis dan Akuntansi. 3, 1. 1072-1083. DOI : https://doi.org/10.35794/emba.v3i1.7867

Lupiyoadi, R. (2012). Manajemen Pemasaran Jasa Teori dan Praktik. Jakarta: Salemba Empat.

Memah, D., Altje, T., Paulina V, R .(2015). Pengaruh Strategi Promosi, Harga Lokasi Dan Fasilitas Terhadap Keputusan Pembelian Rumah Di Citraland Manado. Jurnal EMBA. 3, 1. 1263-1273. DOI : https://doi.org/10.35794/emba.v3i1.8285

Nityasari, A. H., Sutopo. (2013). Analisis Pengaruh Kualitas Pelayanan Terhadap Kepuasan Pengguna Jasa Jamaah Umroh Tahun 2010-2012 (Studi Kasus Pada PT Fatimah Zahra 
Semarang). Diponegoro Journal of Management. 1, 2. 82-90. Diakses dari https://ejournal3.undip.ac.id/index.php/djom/article/view/9011

Raharjaputra, H, S. (2011). Manajemen Keuangan dan Praktis. Jakarta: Salemba Empat.

Ramadhani, N, H. (2017). Pengaruh Kualitas Pelayanan Terhadap Kepuasan Pelanggan PT.

Basmatour \& Travel. Diakses dari Universitas Muhammadiyah Malang, Institusional Repository, http://eprints.umm.ac.id/34747/.

Sugiyono. (2016). Metode Penelitian Kuantitatif Kualitatif dan H\&D. Bandung: Alfabeta.

Tjiptono, F. (2012). Pemasaran Strategik. Yogyakarta: ANDI. 